\title{
ANALYSIS OF PERFORMANCE OF SHORT TREE LOGGING WITH FARM TRACTOR AND LOGGING TRAILER
}

\author{
Mariusz Kormanek ${ }^{*}$, Mateusz Fiszer \\ Institute of Forest Utilization and Forest Technology, Department of Forest Works Mechanization \\ "Corresponding author:e-mail: rlkorma@cyf-kr.edu.pl
}

\begin{tabular}{l}
\hline ARTICLE INFO \\
\hline Article history: \\
Received: December 2017 \\
Received in the revised form: \\
March 2018 \\
Accepted: April 2018 \\
\hline Key words: \\
logging unit, \\
performance, \\
working time structure
\end{tabular}

ABSTRACT
The paper presents analysis of efficiency of the logging unit compri-
sing Belarus 820 farm tractor and PD80 logging trailer equipped with
Ryś-1 crane. Analysis was made based on the working day timing.
The unit logged 1 - meter long tree pieces (hornbeam, oak, birch) from
the area where material for logging was distributed irregularly on the
entire felling site. Unfavourable atmospheric conditions were reported
during the working day (a thick layer of snow, low temperature, not
frozen soil) which could have influenced the unit operation perfor-
mance. Despite that the performance of the logging unit was compara-
ble to similar logging units described in the literature. Determined
coefficient of use of the operating time of the machine $K_{02}$ was 0.93 ,
coefficient of use of the shift working time $K_{04}-0.9$, coefficient of use
of the shift exploitation time $K_{07}-0.8$. Hourly performance in the shift
exploitation time was $4.98 \mathrm{~m}^{3} \cdot \mathrm{h}^{-1}$, efficiency in the shift working time
$W_{02}-4.80 \mathrm{~m}^{3} \cdot \mathrm{h}^{-1}$ and performance in the general shift time $W_{07}-4.30$
$\mathrm{~m}^{3} \cdot \mathrm{h}^{-1}$.

\section{Introduction}

In Poland, universal farm tractors supplemented with specialist technological devices are quite often used for tree logging (Gil, 2007; Więsik, 2017a). There are several reasons for that situation. First of all, majority of Poland has small and dispersed forests which causes that logging tasks are also small and dispersed (Zychowicz and Kasprzyk, 2014). Another reason is that professional forest machines like a skidder or forwarder are considerably expensive and not so available for small enterprises which render services for the State Forest Farm State Forests. Moreover, small forest farms, which own universal farm tractors may carry out, except for seasonal cultivation and protection works, tree logging and achieve performance high enough to ensure favourable economic results for the enterprise (Więsik, 2015, Więsik, 2017a). Universal tractors adjusted for logging are equipped, as a rule, in wire rope winches, loaders, grippers or cranes and special semi-trailers with stanchions. As a rule, winches, grippers and loaders are suspended on the three-point suspension system and so equipped machines can be similarly used as gripping or line skidders. On the other hand, the use of semi-trailers with stanchions, often equipped with hydraulic cranes, forms units analogous to a forwarder (Dudek, 2009; Gil, 2007; Więsik, 2015, 2017a, 2017b). According to recommendations the unit equipped with a tractor plus 
a trailer should be used mainly as an additional logging mean in the conditions of low concentration of raw material at larger distances of logging or a chassis (Rzadkowski, 1995). A tractor should be equipped with all-wheel drive and a hydraulic system with an increased performance (Więsik, 2015). On the other hand, universal farm tractors working in a forest should be appropriately equipped, because work in the forest during logging is dangerous both for an operator and for a tractor. Most often, these are additional shields which protect the machine elements in the form of steel plates welded to the bottom part of the machine and net grating of a radiator and an engine, tractor cars, which are certified or in the form of steel poles, 10-12 layer tyres with shields for valves welded to the rim, facilitation of control of additional equipment operation and in this case, first of all, a rotary chair (Gil, 2007; Zychowicz, 2010). In Poland more and more companies dealing with forest machines offer adjustment of universal farm tractors for work in a forest. An increasing number of producers and presented logging trailers aggregated with farm tractors have been reported in the recent years on global markets (Wojtkowiak et al., 2009). Such a development trend takes place also in Poland. In 2004, participation of universal tractors in logging was at the level of $60 \%$ with a raising trend (Dudek, 2009). According to Więsik (2017a) quoting the State Forests Development and Implementation Centre in Bedon in 2012 in 945 forest companies (approximately 1/3 of all in the country) which carried out tasks for the State Forests the following were used for logging: 233 forwarders, 537 skidders, 847 logging trailers without a crane and 950 with a crane and 2917 farm tractors. On the other hand, based on the own research carried out in 2014 Więsik (2017 a) confirms that units comprising a farm tractor and self-loading trailers have become a basic mean of forest companies for skidding logging. Although, logging units comprising a tractor and a logging trailer are more and more often used, there is no much information on the performance parameters of this type of units (Gil, 2007; Więsik, 2017a). The objective of the paper was to present analysis of the logging performance for the unit working based on Belarus 820 tractor popular in Poland and logging trailer PD 80 by Długpol equipped with crane Ryś-1.

\section{Materials and methods}

The research was carried out on the territory of Taczanów Forest Inspectorate, Koryta Forestry. On the area of research - a habitat forest site type fresh forest, strongly fresh variant and soil - light sandy clay with a layer of average loamy sand and a layer of turf. Species composition in the place of research is as follows: $5 \mathrm{Ol}$ [alder], $3 \mathrm{~Gb}$ [hornbeam], $1 \mathrm{Brz}$ [birch], $1 \mathrm{Db}$ [oak], stand density rate 0.9 , medium density, age of a tree stand 84 years (alder, hornbeam, birch), oak 100 years, single oak 210 years. Trees were cut with a sowing machine and felt with a tilt direction without concentration of logging residues. When the logging was completed, there were no clear branch and wood zones visible. Logs and logging residues were distributed randomly on the entire felling area and not arranged. The subject of analysis was a logging unit (Fig, 1; Table 1) comprising Belarus 820 tractor (6 years of exploitation) and a logging trailer PD 80 (1 year of exploitation) with mounted crane Ryś-1. 


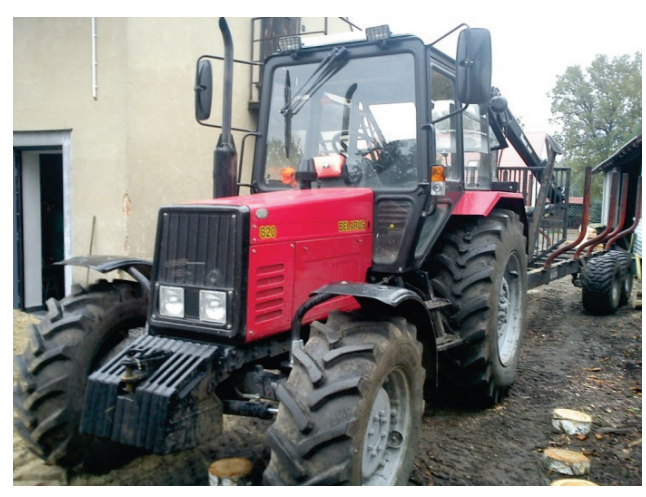

a



Source: M. Fiszer

Figure 1. Belarus 820 and PD80 trailer with loader Ryś -1

Measurements were carried out 20 December when a thick layer of snow was present and with temperature of $-13^{\circ} \mathrm{C}$. The unit cut $1 \mathrm{~m}$ long logs of hornbeam, oak and birch from the entire felling area (on the entire length of felling). A measurement was carried out during a working shift with a stopwatch $( \pm 1 \mathrm{~s})$, times which the unit needed to perform particular operations related to loading and unloading of wood. An ultrasonic rangefinder $( \pm 30$ $\mathrm{cm})$ was used for measuring distances made by the machine and a measuring tape $( \pm 1 \mathrm{~mm})$ was used for measuring the length, width and height of piles which the unit logged on the day of research, which after conversion allowed determination of the load in square metres of the load $Q\left(\mathrm{~m}^{3}\right)$. During the measurements, a distance from the log yard to the place where logging was carried out $L_{\text {odskt }}(\mathrm{m})$, distance made during logging $L_{z a t}(\mathrm{~m})$, and distance from the place where the loading was completed to the $\log$ yard $L_{\text {doskt }}(\mathrm{m})$ were determined. Distances of crossings were measured from the centre of the zone where the loading was carried out. Based on the time measurements and measured distances, the driving speed was measured in $\left(\mathrm{m} \cdot \mathrm{s}^{-1}\right)$ without loading $V_{\text {beztad }}$, when loading was carried out $V_{\text {zatad }}$ and the loading set $V_{\text {zlad }}$. Agricultural standards BN-76/9195-01 and BN-77/9195-02 which were modified for agricultural purposes served for analysis of operational parameters (Zychowicz and Kasprzyk 2014).

The following elements were selected in timing:

- time of the loading cycle of the unit operation $T_{2}$, which included the crossing time of the unit from the log yard to the place where the load is formed $T_{21}$, time of load forming on a trailer (load) $T_{22}$,

- time of technological stopovers related to the logging process carried out by the unit $T_{23}$, time of crossing with a load to the $\log$ yard $T_{24}$, wood unloading time with heap formation $T_{25}$;

- time of a daily technical service and preparation of the machine to operation $T_{3}$;

- technological $T_{41}$ and technical $T_{42}$ faults removal time $T_{4}$

- rest time $T_{5}$,

- transport crossings time $T_{6}$,

- time of everyday service of an accompanying machine $T_{7}$. 
Mariusz Kormanek, Mateusz Fiszer

Table 1.

Basic technical characteristic of the investigated logging unit (Information by Belarus; Information by Dtugpol)

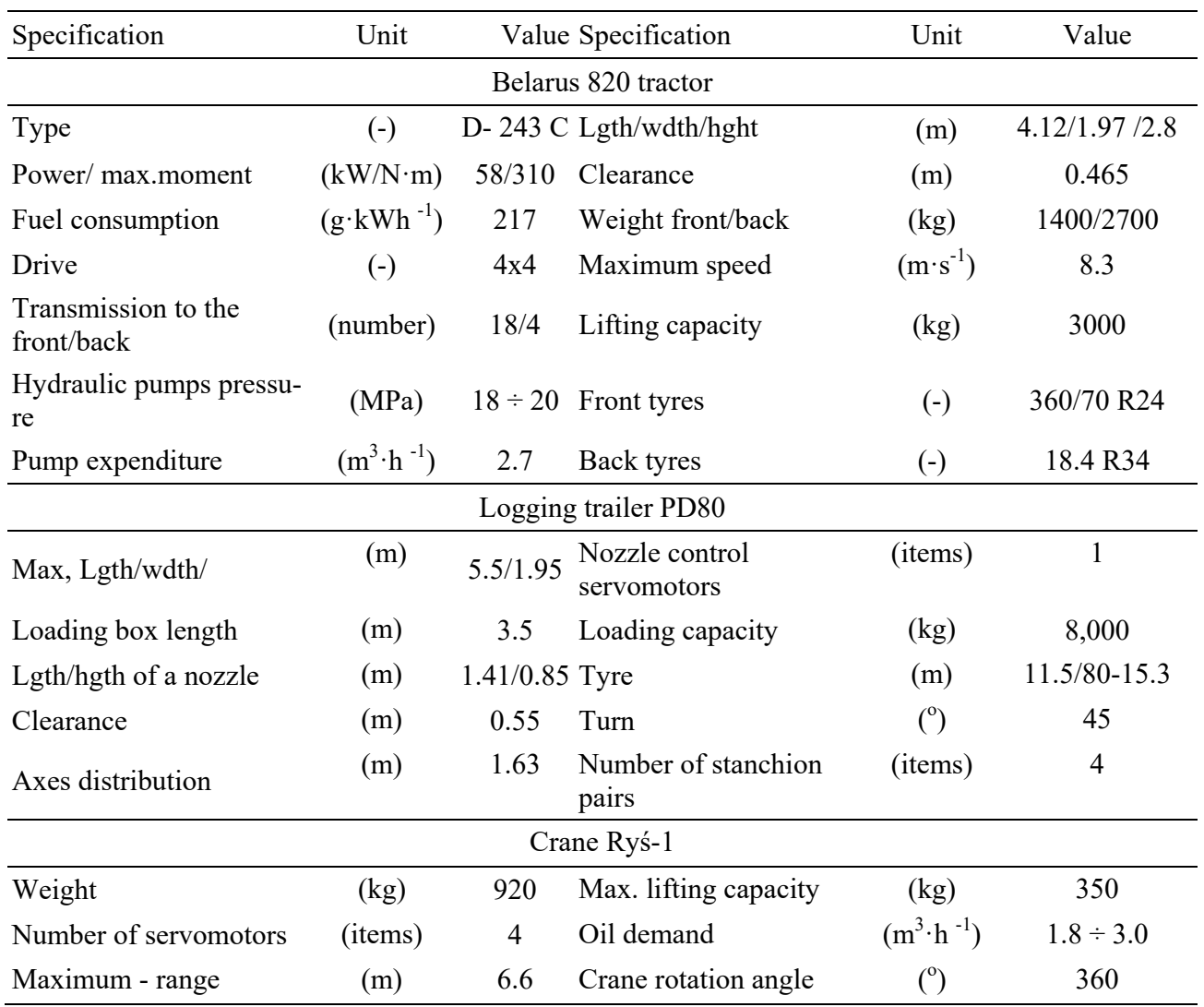

Based on the selected components operational time of the machine $T_{02}$ was calculated; it was assumed that it equals the time of the unit working cycle $T_{2}$, working shift time $T_{04}$, general shift time $\mathrm{T}_{07}$. Moreover, the coefficient of use of the operating working time of the machine $K_{02}$, coefficient of use of the shift working time $K_{04}$, coefficient of use of the shift exploitation time $K_{07}$ were determined. It enabled determination of the operational performance of logging $W_{02}$, performance in the working shift time $W_{04}$ and performance in the general shift time $W_{07}$.

\section{Results}

During the monitored 7-hour work day, 5 logging cycles were carried out and the total load $Q-30.6 \mathrm{~m}^{3}$ of wood was logged (Table 2, Figure 2 and 3 ). 
Analysis of performance...

Table 2.

Characteristics of the logged loads, speed and distance of crossings and elements of timing

\begin{tabular}{|c|c|c|c|c|c|}
\hline Parameter & Unit & Result & Parameter & Unit & Result \\
\hline $\mathrm{n}_{\text {tad }}$ & (items) & 5 & $\mathrm{~T}_{21}$ & (s) & 3927 \\
\hline$Q_{\text {średni }}$ & $\left(\mathrm{m}^{3}\right)$ & $6.11 \pm 0.35$ & $\mathrm{~T}_{22}$ & (s) & 8613 \\
\hline Q & $\left(\mathrm{m}^{3}\right)$ & 30.6 & $\mathrm{~T}_{23}$ & (s) & 1500 \\
\hline Qśredni teoret & $\left(\mathrm{m}^{3}\right)$ & 7.41 & $\mathrm{~T}_{24}$ & (s) & 3891 \\
\hline $\mathrm{Q}_{\text {teor }}$ & $\left(\mathrm{m}^{3}\right)$ & 37.05 & $\mathrm{~T}_{25}$ & (s) & 4162 \\
\hline$V_{\text {bezład }}$ & $\left(\mathrm{m} \cdot \mathrm{s}^{-1}\right)$ & $0.98 \pm 0.18$ & $\mathrm{~T}_{2}$ & (s) & 22093 \\
\hline $\mathrm{V}_{\text {załad }}$ & $\left(\mathrm{m} \cdot \mathrm{s}^{-1}\right)$ & $0.48 \pm 0.12$ & $\mathrm{~T}_{3}$ & (s) & 600 \\
\hline $\mathrm{V}_{\text {zlad }}$ & $\left(\mathrm{m} \cdot \mathrm{s}^{-1}\right)$ & $0.66 \pm 0.14$ & $\mathrm{~T}_{4}$ & (s) & 240 \\
\hline $\mathrm{L}_{\text {odskt }}$ & (m) & $770 \pm 191$ & $\mathrm{~T}_{5}$ & (s) & 1500 \\
\hline $\mathrm{L}_{\text {zał }}$ & (m) & $255 \pm 84$ & $\mathrm{~T}_{6}$ & (s) & 1160 \\
\hline $\mathrm{L}_{\text {doskt }}$ & (m) & $514 \pm 120$ & $\mathrm{~T}_{7}$ & (s) & 0 \\
\hline
\end{tabular}

The unit working time which included getting to the $\log$ yard $\log \operatorname{yard} T_{21}$, loading $T_{22}$, getting to the unloading place $T_{24}$ and unloading $T_{25}$, took $80.46 \%$ (6h 12 minutes) during the working cycle of the machine $T_{2}$ and $86.3 \%$ in the exploitation time of the working shift $T_{07}$ (tab. 2 and 3, figure 2 and 3). The impact of the load size on the loading and unloading of the trailer time shift is clear (Figure 2). With the increase by $0.85 \mathrm{~m}^{3}$ (the maximum load minus the minimal one) the loading time increases by $16.4 \%$ and the unloading time by $36.9 \%$. Analysis of the movement of unit B820+PD80 during the work cycle enables to state that the movement speed during a crossing with a load and without a load (table 2) were similar to the speed provided by Moskalik (2004) based on the analysis of the logging unit operation, which included universal tractor Ursus 1014 cooperating with logging trailer JAR8 (loading capacity of the trailer was also $8 \mathrm{t}$ ). This unit logged average size cutlogs with the length of $2.4 \mathrm{~m}$ in early thinning from logging routes located in the distance of 20 $\mathrm{m}$ from each other, at the average distance of the wood logging $340 \mathrm{~m}$ (the scope of changes from $100 \mathrm{~m}$ to $870 \mathrm{~m}$ ) and the average load $8.1 \mathrm{~m}^{3}$. Driving speed with the load for U1014+JAR8 was $0.65 \mathrm{~m} \cdot \mathrm{s}^{-1}$ and without the load was $0.95 \mathrm{~m} \cdot \mathrm{s}^{-1}$. Only in case of the average speed of the unit movement during preparation of the load, unit U1014+JAR8 speed was lower and it was $0.39 \mathrm{~m} \cdot \mathrm{s}^{-1}$ when for B820+PD80 it was $0.48 \mathrm{~m} \cdot \mathrm{s}^{-1}$ (Table 2). In this case, the reasons could have been a larger size of average loads logged by the units (U1014+JAR8 $-8.1 \mathrm{~m}^{3}$; B820+PD80 $-6.1 \mathrm{~m}^{3}$ ), and thus a longer loading time, but also irregular distribution of the wood raw material on the felling area and difficulties in crossing the felling area. A similar comparison can be made with regard to the logging unit comprising Zetor 8045 tractor and PD80 trailer with crane Ryś-1 analysed by Zychowicz and Kasprzyk (2014). This unit made $2.5 \mathrm{~m}$ logs (61 years old poplar, hornbeam, birch and oak) where the average load was $3.25 \mathrm{~m}^{3}$ and logging took place at the distance with the average length of $174 \mathrm{~m}$. In this case the area was also difficult and the wood was scattered on the area which forced repeated manouvres. The average time of loading for unit Z8045+PD80 was $1008 \mathrm{~s}(16$ minutes $48 \mathrm{~s})$ and was lower than the time of the entire loading with units B820+PD80 - $1722(28 \min 42 \mathrm{~s})$ and U1014+JAR8 - $1530 \mathrm{~s}(25 \min 30 \mathrm{~s})$. The average 
speed of movement of the unit Z8045+PD80 with the load is $0.96 \mathrm{~m} \cdot \mathrm{s}^{-1}$ and was higher than the investigated unit B820+PD80 where it was $0.66 \mathrm{~m} \cdot \mathrm{s}^{-1}$ as well as for the compared $\mathrm{U} 1014+\mathrm{JAR} 8$ where it was $0.65 \mathrm{~m} \cdot \mathrm{s}^{-1}$.

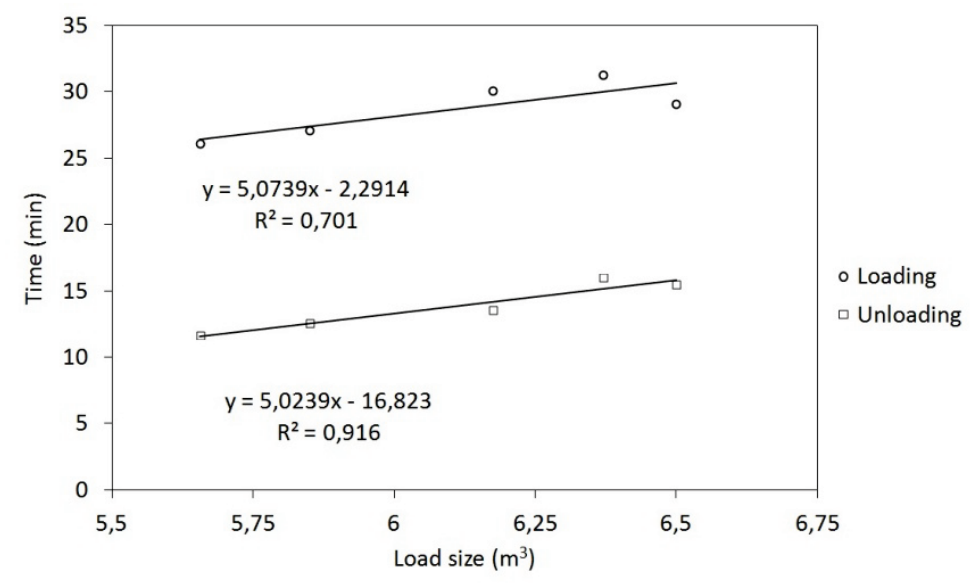

Figure 2. Loading and unloading shift time in the function of the load size logged by the logging unit

On the other hand, average time of the unloading cycles are comparable, where for U1014+JAR-8, it is $846 \mathrm{~s}(14 \mathrm{~min} 6 \mathrm{~s})$, and for B820+PD80 - $832 \mathrm{~s}(13 \mathrm{~min} 54 \mathrm{~s})$. Decisively lower values were reported for Z8045+PD $80-684 \mathrm{~s}(11 \mathrm{~min} 24 \mathrm{~s})$. Time of technological stopovers $T_{23}$, where logs were searched under snow took, in case of the investigated unit B820+PD80, as much as $6.78 \%(25 \mathrm{~min})$ in the operational time of the unit $T_{02}$ and $5.86 \%$ in the operational time of the working shift $T_{07}$. Participation of the rest time in the operational cycle provided by Zychowicz and Kasprzyk (2014) for the unit Z8045+PD80 was lower and it was 4\%. In case of the analysed unit B820+PD80 it should be emphasised that an assistant was of great help during searching for logs. As a rule, when an operator loaded logs to a trailer, an assistant looked for them in snow. If it was not for him, the operator must have done it by himself and as a result the time of technological stopovers would have been extended. The average time of the logging cycle in case of B820+PD80 was $4418.6 \mathrm{~s}$ (6 h $8 \mathrm{~min} 13 \mathrm{~s}$ ) for Z8045+PD80 - $2052 \mathrm{~s} \mathrm{(34} \mathrm{min} 12 \mathrm{~s})$ (Zychowicz and Kasprzyk 2014) thus it is decisively lower, which should be related to the size of logged loads (B820+PD $80-6.11 \mathrm{~m}^{3}$, and Z8045+PD80-3.25 $\left.\mathrm{m}^{3}\right)$. The remaining elements of the time structure in the working cycle (figure $3 \mathrm{a}$ ) for B820+PD80 is the time of reaching $17.8 \%$ (Z8045+PD80 - 9.0\%), loading 39.0\% (Z8045+PD80 - 47.0\%), crossing with the load of $17.6 \%$ (Z8045+PD80 - 8\%) and unloading 11.8\% (Z8045+PD80-32\%). These significant differences in the percentage participation of particular components result mainly from a bigger distance of the felling area. For B820+PD80 the average distance from the log yardto the place where the load forming is carried out is $770 \mathrm{~m}$, the average distance made during load forming is $214 \mathrm{~m}$, and the average distance run from the moment the trailer is loaded to the log yard is $514 \mathrm{~m}$, when for the unit Z8045+PD80 the average distance of the logging area is $174 \mathrm{~m}$ (Zychowicz and Kasprzyk 2014). For the cycle time structure, diffe- 
Analysis of performance...

rences in the sizes of the logged loads will be of great significance, which was mentioned earlier. The time of a daily technical service $T_{3}$ which is $600 \mathrm{~s} \mathrm{(10} \mathrm{minutes)} \mathrm{was} 2.34 \%$ of the working shift and was devoted to everyday machine inspection including the control of the liquid level (coolant, oil in the engine and in the hydraulics). Moreover, the machine was started, heated and fuel was added within this time. With atmospheric conditions on the day of the research $\left(-13^{0} \mathrm{C}\right)$ in view, this is a very good result. The time of technical faults removal $T_{4}$ was 240 seconds (4 minutes) which is $0.94 \%$ in the working day structure. The fault, namely oil dripping from the point of connection of hydraulic hoses with a rotator, were found and removed at the beginning of the unit operation. The rest time and physiological needs time $T_{5}$, lasted 25 minutes and constituted $5.86 \%$ of the working day structure (regeneration break, food and physiological needs). The total time of transport crossings $T_{6}$, namely from the base to the working place and back took 19 minutes 20 seconds which constitutes $4.53 \%$ in the working day structure. Because of the icy road this result should be recognised as good. The felling area was in the distance of approx. $800 \mathrm{~m}$ from the base $2 / 3$ of the route was an asphalt road. Such a good result was a consequence of the agreement with a forester - nurseryman who agreed to station the unit on the area of the nursery. There was no time of technical service of the accompanying machine $T_{7}$. Obtained during the working day high coefficients of use of the working time of the machine $K_{02}$ was 0.93 , coefficient of use of the shift working time $K_{04}-0.9$, coefficient of use of the shift exploitation time $K_{07}-0.8$ (table 4) are slightly lower than those indicated by Zychowicz and Kasprzyk (2014) for Z8045+PD80 $\left(k_{02}-0.99, K_{04}-0.93, K_{08}-0.83 ; K_{08}\right.$ and $W_{08}$ in the paper by Zychowicz and Kasprzyk (2014) correspond to $K_{07}$ and $W_{07}$ calculated in this paper). The calculated coefficients could have translated into high logging performance; however, in this case the situation is different. Hourly performance in the shift exploitation time of the logging unit was $4.98 \mathrm{~m}^{3} \cdot \mathrm{h}^{-1}$, performance in the working shift time $W_{02}$ was $4.98 \mathrm{~m}^{3} \cdot \mathrm{h}$ ${ }^{1}$, and performance in the working shift time $W_{04}-4.80 \mathrm{~m}^{3} \cdot \mathrm{h}^{-1}$, a , performance in the general shift time $W_{07}-4.30 \mathrm{~m}^{3} \cdot \mathrm{h}^{-1}$ (table 4 ) and these values are lower than those provided by Zychowicz and Kasprzyk (2014) for Z8045+PD80, where $W_{02}-5.68, \mathrm{~m}^{3} \cdot \mathrm{h}^{-1}, W_{04}-5.32$ $\mathrm{m}^{3} \cdot \mathrm{h}^{-1}$, and $W_{08}-4.72 \mathrm{~m}^{3} \cdot \mathrm{h}^{-1}$



a

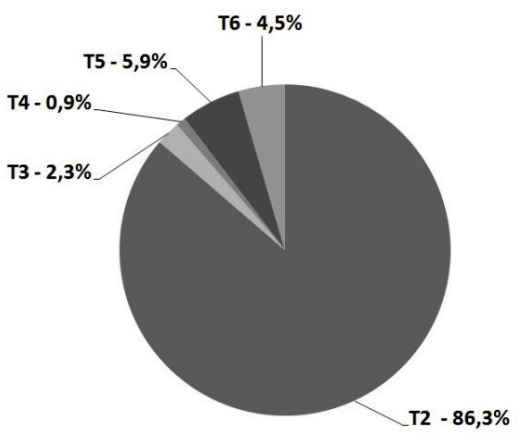

b

Figure 3. Percentage share of components of the logging cycle $-a$ and working shift $-b$ of the analysed logging unit 
Several factors influenced weaker performance results in case of B820+PD 80. Mainly, the unit was not used fully; theoretical loading capacity for this trailer Qteor is $7.41 \mathrm{~m}^{3}$. However, real use $Q_{\text {sredni }}$ was at the level of $6.11 \mathrm{~m}^{3}$ which is $82.5 \%$ of the loading space of the trailer (table 2). According to Więsik (2017b) the problem when standard dimensions of loading boxes at the varied length of logs do not provide for absolute use of the unit, have already been reported and producers modify the structure of trailers. For the considered unit, at the fully loaded trailer, one may obtain performance in the general sift time $W_{07 \text { teoret }}$ at the level of $5.21 \mathrm{~m}^{3} \cdot \mathrm{h}^{-1}$ (Table 4).

Table 3.

Balance of the working day of investigated logging unit

\begin{tabular}{lccccc}
\hline Parameter & Unit & Result & Parameter & Unit & Result \\
\hline $\mathrm{T}_{02}$ & $(\mathrm{~s})$ & 22093 & $\mathrm{k}_{07}$ & $(-)$ & 0.8 \\
$\mathrm{~T}_{42}$ & $(\mathrm{~s})$ & 240 & $\mathrm{~W}_{02}$ & $\left(\mathrm{~m}^{3} \cdot \mathrm{h}^{-1}\right)$ & 4.98 \\
$\mathrm{~T}_{07}$ & $(\mathrm{~s})$ & 25593 & $\mathrm{~W}_{04}$ & $\left(\mathrm{~m}^{3} \cdot \mathrm{h}^{-1}\right)$ & 4.80 \\
$\mathrm{k}_{02}$ & $(-)$ & 0.93 & $\mathrm{~W}_{07}$ & $\left(\mathrm{~m}^{3} \cdot \mathrm{h}^{-1}\right)$ & 4.30 \\
$\mathrm{k}_{04}$ & $(-)$ & 0.90 & $\mathrm{~W}_{07 \text { teor }}$ & $\left(\mathrm{m}^{3} \cdot \mathrm{h}^{-1}\right)$ & 5.21 \\
\hline
\end{tabular}

The above-mentioned incomplete use of a trailer resulted mainly from the fact that the unit logged trees with dimensions not adjusted to this structure of the trailer (1-metre long cutlogs). According to the producer, the length of wood used for this trailer should not be shorter than $1.4 \mathrm{~m}$ (information material of Długpol). Distribution of stanchions allowed then to place two rows of logs which caused that the real performance was not so high as it could have been. Moreover, 1-metre long logs often slipped from the trailer between stanchions which extended the loading time. Additional pairs of stanchionscould be a solution to the problem. Then, the unit could fully use its loading capacity by loading three instead of two rows of 1-metre long logs. Another factor influencing the performance was availability of the site and necessity to log wood from the entire felling area (disorganized logging, where logs were scattered on the entire length and width of the felling site). According to Stempski (2012), when the felling site is organized, namely, when trees for logging are located on both sites of the branches zone where a forwarder is moving, and the branches zone where a forwarder is moving indicates the crossing time, then the number of crossings may decrease by even $30 \%$ and the average time of crossing may be reduced by $16 \%$. On the other hand, in case of a disorganized felling site, the loading time may be almost $1 / 3$ longer in comparison to the organized felling site. The next factor, which could have affected the reduction of the performance were atmospheric conditions because during the research, despite frost, soil under snow was frozen, which in relation to a thick layer of snow $(35 \mathrm{~cm})$ affected the driving speed with which the logging unit was moving (wheel tracks were $40 \mathrm{~cm}$ ). The snow cover also forced the operator to go out of the tractor many times and search for logs in snow together with the assistant. Such organization of works which would enable to carry out logging systematically, namely such organization of works that a sowman performs felling in one corner of the felling site and the unit performs logging in the second corner, would help to solve the problem. An important factor that reduced per- 
Analysis of performance...

formance, which can be also taken into consideration, was a failure to adjust Belarus 820 tractor to logging and in this case, mainly, lack of a rotational chair of the driver. The logging unit operator performed all activities related to wood loading from the kneeling position on the driver's chair. Working in such an uncomfortable position made the worker complaint to spine pain at the end of the work day; undoubtedly, the work was tiresome.

\section{Conclusions}

The following conclusions may be formulated by analysis of the performance of the investigated unit for skidding logging.

1. During a monitored working day, despite bad atmospheric conditions, high coefficients of use of the operating time of the machine $K_{02}$ was 0.93 , coefficient of use of the working shift time $K_{04}-0.9$, coefficient of use of the exploitation shift time $K_{07}-0.8$ were obtained.

2. Hourly performance in the operational logging time for the analysed unit was $4.98 \mathrm{~m}^{3} \cdot \mathrm{h}^{-1}$, performance in the working shift time $\mathrm{W}_{02}$ was $4.98 \mathrm{~m}^{3} \cdot \mathrm{h}^{-3}$, and performance in the working shift time $W_{04}-4.80 \mathrm{~m}^{3} \cdot \mathrm{h}^{-1}$, a , performance in the general shift time $W_{07}-4.30 \mathrm{~m}^{3} \cdot \mathrm{h}^{-1}$.

3. To improve performance of the logging unit operation, comprising Belarus 820 tractor and logging trailer type PD80 equipped with crane Ryś-1, it should be used for logging of logs compliant to the producer's requirements or the logging trailer should be better adjusted to logging logs with smaller dimensions.

\section{Funding}

The study was financed from the subsidy of the Ministry of Science and Higher Education for statute activity.

\section{References}

Dudek, T. (2009). Wydajność zrywki drewna długiego na zrębie zupełnym ciągnikiem rolniczym z wciągarką lub kleszczami hydraulicznymi. Sylwan 153(6), 386-392.

Gil, W. (2007). Badania porównawcze ciagników rolniczych jako środków zrywkowych w wybranych zakładach ustug leśnych. Rozprawy zeszyt 316. Wydawnictwo AR w Krakowie. 128.

Mat. infromacyjne Długpol. Strona internetowa: http://www.dlugpol.pl/.

Mat. infromacyjne Belarus. Strona internetowa: http://lupus-wilk.com.pl.

Moskalik, T. (2004). Model maszynowego pozyskania drewna w zrównoważonym leśnictwie polskim. Wydawnictwo SGGW Warszawa. ISBN 83-7244-491-9.

Rzadkowski, S. (1995). Wydajność oraz koszty zrywki drewna forwarderem i przyczepą kłonicową agregatowaną z ciągnikiem rolniczym. Przegląd Techniki Rolniczej i Leśnej, 7, 8-10.

Stempski, W. (2012). Wpływ sposobu przygotowania drewna na czas formowania ładunku forwarderem. Nauka Przyroda Technologia, 6(4), 1-10.

Więsik, J. (2015). Urządzenia techniczne w produkcji leśnej. Wydawnictwo SGGW. 591. ISBN9787583-219-9.

Więsik, J. (217a). Jak tworzyć i efektywnie użytkować agregaty zrywkowe z przyczepą nasiębierną. Część 1. Opis procesu zrywki nasiębiernej i zasady tworzenia agregatu Technika Rolnicza Ogrodnicza Leśna, 4, 18-21. 
Więsik, J. (217b). Jak tworzyć i efektywnie użytkować agregaty zrywkowe z przyczepą nasiębierną. Część 2. Wpływ długości drewna na efekty zrywki przyczepą nasiębierną. Technika Rolnicza Ogrodnicza Leśna, 4, 15-18.

Wojtkowiak, R., Bitner, W., Mac, J., Zembrowski, K. (2009). Międzynarodowe Targi Leśne Elmia Wood 2009. Technika Rolnicza Ogrodnicza i Leśna, 4, 15-17.

Zychowicz, W. (2010). Maszyny i urządzenia do transportu drewna. Drwal, 4, 38-41.

Zychowicz, W., Kasprzyk K. (2014). Effectiveness of agricultural tractor utilization in the wood skidding and forwarding. Annals of Warsaw University of life sciences - SGGW. Agriculture, 63 , 113- 123.

BN-77/9195-02. Norma branżowa. Metody badań eksploatacyjnych. Maszyny rolnicze. Wydawnictwa normalizacyjne. Warszawa. 1.

BN-76/9195-01. Norma branżowa. Podział czasu pracy. Symbole i określenia. Maszyny rolnicze Wydawnictwa normalizacyjne. Warszawa. 2.

\section{ANALIZA WYDAJNOŚCI ZRYWKI DREWNA KRÓTKIEGO PRZY UŻYCIU CIĄGNIKA ROLNICZEGO I PRZYCZEPY ZRYWKOWEJ}

Streszczenie. W pracy przedstawiono analizę wydajności zestawu zrywkowego składającego sie z rolniczego ciągnika uniwersalnego Belarus 820 oraz przyczepy zrywkowej PD 80 wyposażonej w żuraw Ryś-1. Analizy pracy zestawu dokonano w oparciu o chronometraż dnia roboczego. Zestaw w trakcie badań zrywał sortyment o długości 1 metra (grab, dąb, brzoza) z powierzchni gdzie materiał do zrywki był rozłożony w sposób nieuporządkowany na całej powierzchni zrębu. Jak stwierdzono w ciągu dnia roboczego panowały niesprzyjające warunki atmosferyczne (gruba warstwa śniegu, niska temperatura, niezamarznięta gleba), co mogło wpłynąć na efektywność pracy zestawu. Mimo to, wydajności uzyskane przez zestaw zrywkowy były porównywalne z podobnymi zestawami zrywkowymi opisywanymi w literaturze. Wyznaczony współczynnik wykorzystania operacyjnego czasu pracy maszyny $K_{02}$ wyniósł 0,93 , współczynnik wykorzystania roboczego czasu zmiany $K_{04}-0,9$, współczynnik wykorzystania eksploatacyjnego czasu zmiany $K_{07}-0,8$. Godzinowa wydajność w eksploatacyjnym czasie zmiany $W_{02}$ wyniosła $4,98 \mathrm{~m}^{3} \cdot \mathrm{h}^{-1}$, wydajność w roboczym czasie zmiany $W_{02}-4,80 \mathrm{~m}^{3} \cdot \mathrm{h}^{-1}$, a wydajność w ogólnym czasie zmiany $W_{07}-4,30 \mathrm{~m}^{3} \cdot \mathrm{h}^{-1}$.

Słowa kluczowe: agregat zrywkowy, wydajność, struktura czasu pracy 